EMPOWER : Jurnal Pengembangan Masyarakat Islam

Vol. 5, No.1, Juni 2020, hlm. 133-154

e-ISSN : 2580-0973, p-ISSN : 2580-085X

Tersedia Online di : http://syekhnurjati.ac.id/jurnal/index.php/empower

Email : empowerjurnal@gmail.com

\title{
Pabrik Bulu Mata Palsu dan Ruang Kuasa Perempuan Buruh (Kajian Etnografis di Desa Pasunggingan, Kecamatan Pengadegan, Kabupaten Purbalingga, Jawa Tengah)
}

\author{
Nurlaili Khikmawati, S.Pd., M.Ant \\ (Prodi Pengembangan Masyarakat Islam, Fakultas Ushuluddin Adab dan Dakwah, \\ IAIN Syekh Nurjati Cirebon) \\ E-mail: lailinur.kh0306@gmail.com
}

Article History

Submitted: 28.04.2020; Revised: 23.05.2020; Accepted: 21.06.2020;

\begin{abstract}
The study regarding women labor is always interesting to done. This is due to the domestic roles of women that women labor has a double burden for work in the factory and work in the household/domestic area. In addition, the placement of women in the domestic area makes "labor" is not always statistically calculated as a job and the work status of women remains as a housewife. Another challenge faced by women when working as labor is the emergence of public assumptions about the existence of women's power in the household, including their power to sue for divorce. These assumptions about the domestic life of women labor encourage researcher to conduct a study of the power of women (labor) in the household as an effect of industrialization, in terms of access and control over resources and decision making in the household. This research was conducted using ethnographic methods in Pasunggingan Village, Pengadegan Subdistrict, Purbaingga Regency, Central Java as one of the villages that has a high number of women labors. The results of this study revealed that the establishment of a false eyelash industry in the village area had attracted women in Pasunggingan Village to conduct economic migration. This migration is carried out for a variety of reasons both economic and non-economic which impact on the income of women (and households) and changes in the lifestyle of women and society. The entry of women into the
\end{abstract}


industrial sector has made women has a higher bargaining value in the household and can open a household into a wider area.

Keywords: Labor, Women, Household.

\begin{abstract}
Abstrak
Kajian mengenai perempuan buruh merupakan kajian yang selalu menarik untuk dilakukan. Hal ini dikarenakan keterlekatan peran domestik pada diri perempuan sehingga buruh perempuan memiliki tanggung jawab ganda pada pekerjaannya di pabrik dan pekerjaannya di rumah tangga. Selain itu, penempatan perempuan dalam wilayah domestik membuat "buruh" menjadi pekerjaan yang tidak selalu dihitung secara statistik sehingga status pekerjaan peremuan tetap sebagai ibu rumah tangga. Tantangan lain yang dihadapi perempuan saat masuk ke dunia buruh adalah munculnya asumsi-asumsi publik tentang adanya kuasa perempuan di dalam rumah tangga termasuk kuasanya dalam menggugat cerai pasangannya. Beberapa asumsi mengenai kehidupan rumah tangga buruh perempuan, ini mendorong peneliti untuk melakukan kajian mengenai kuasa perempuan (buruh) di dalam rumah tangga sebagai akibat dari adanya industrialisasi, dilihat dari akses dan kontrolnya terhadap sumber daya dan pengambilan keputusan di dalam rumah tangga. penelitian ini dilakukan dengan metode etnografi di Desa Pasunggingan Kecamatan Pengadegan Kabupaten Purbaingga, Jawa Tengah sebagai salah satu desa yang memiliki buruh perempuan dengan angka ang cukup tinggi. Hasil penelitian ini mengungkapkan bahwa berdirinya pabrik bulu mata palsu di wilayah desa telah menarik perempuan di Desa Pasunggingan untuk melakukan migrasi ekonomi. Migrasi ini dilakukan dengan berbagai alasan baik ekonomi maupun non ekonomi yanag berimbas pada penghasilan perempuan dan rumah tangga serta berubahnya pola hidup perempuan dan masyarakat. Masuknya perempuan ke dalam sektor industri juga telah membuat perempuan memiliki ruang khusus yang terbebas dari laki-laki serta memiliki nilai tawar yang lebih tinggi di dalam rumah tangga sehingga mampu membuka rumah tangga menjadi wilayah yang lebih luas.
\end{abstract}

Kata kunci: Buruh, Perempuan, Rumah Tangga. 


\section{PENDAHULUAN}

Kajian mengenai buruh perempuan telah dilakukan sejak lama dan masih menjadi kajian yang menarik hingga saat ini. Hal ini dapat dilihat dari eksisteni forum-forum buruh perempuan dan munculnya forum tersebut pada momen-momen tertentu seperti hari buruh nasional dan mencuatnya isu-isu politik mengenai buruh seperti RUU tentang buruh.

Pada dasarnya keterlibatan perempuan Indonesia di dalam sektor industri telah terjadi sejak lama. Pada tahun 1980an revolusi hijau telah mengurangi ruang perempuan di wilayah pertanian bersamaan dengan pesatnya pertumbuhan industri sehingga menjadi magnet bagi perempuan pedesaan melakukan migrasi ke kota untuk bekerja ${ }^{1}$. Revolusi hijau terjadi ketika suatu teknologi pertanian baru muncul bersamaan dengan bibit unggul yang berproduksi lebih tinggi, pupuk kimia untuk pengendalian hama, alat-alat penghemat tenaga kerja beserta teknik pengolahannya, dan kerangka kelembagaan (koperasi) dalam rangka meningkatkan produktivitas tanaman, meskipun pada kenyataannya revolusi hijau membawa dampak yang signifikan terhadap peran perempuan di sektor ekonomi pertanian karena tenaga perempuan telah diganti oleh alat-alat pertanian modern².

Faktor lain yang mendorong masuknya perempuan ke dalam sektor industri adalah menyempitnya lahan pertanian dan kebijakan pemerintah ${ }^{3}$ serta kondisi ekonomi keluarga yang miskin ${ }^{4}$. Perempuan pada keluarga dengan ekonomi miskin adalah pihak yang paling rentan. Perempuan

\footnotetext{
1 Warto, 'Wanita Pabrikan: Simbol Pergeseran Status Wanita Desa', in Sangkan Paran Gender (Yogyakarta: Pustaka Pelajar, 2006). Dan D Benjamin, ‘Women and the Labour Market in Indonesia during the 1980s', in Women and Industrialization in Asia, ed. by Susan Horton (New york: Routledge, 2003).

2 Ratna Sapari and Briggitte Holzner, Perempuan Kerja Dan Perubahan Sosial (Jakarta: P.T Pustaka Utama Grafiti, 1997).

${ }^{3}$ Erwan Agus Purwanto and Budhy K Zaman, Ups and Downs in Rural Javanese Industry: The Dynamics of Work and Life of Small-Scale Garment Manufacturers and Their Families (Grha Guru, 2005).

4 Resmi Setia, 'Perjalanan Hidup Seorang Buruh Perempuan (Antara Rumah Tangga, Tempat Kerja Dan Komunitas)’, Jurnal Analisis Sosial, 8 (2003), pp. 51-63.
} 
menikah dalam usia dini sebagai strategi keluarga mengurangi beban ekonomi dan setelah menikah perempuan menanggung kekurangan ekonomi keluarga sehingga perempuan turut bekerja.

Namun demikian struktur masyarakat Indonesia yang telah mapan menempatkan perempuan sebagai makhluk domestik sehingga pekerjaan perempuan di pabrik menjadi pekerjaan yang invisible dan tidak selalu diperhitungkan secara statistik. Hal ini sebagaimana dilanggengkan oleh pemerintah orde baru yang telah menentukan ibu rumah tangga sebagai fungsi utama perempuan di dalam masyarakat sehingga status perempuan sebagai pekerja disubordinasi oleh status perempuan sebagai ibu rumah tangga ${ }^{5}$.

Migrasi perempuan ke dalam sisem ekonomi industri membuat sistem kerja perempuan mengalami perubahan, di samping perubahan pada sistem upah yang lebih terstruktur. Sistem upah yang lebih terstruktur membawa perubahan pada pola hidup perempuan dan menghubungkan perempuan pada proses modernisasi serta redefinisi perempan ${ }^{6}$.

Sebelum tahun 90-an, perempuan dikatakan sebagai wanita yang berarti wani di tata. Artinya, perempuan adalah objek yang harus menaati berbagai peraturan yang mengikat seperti perempuan memiliki kodrat sebagai ibu dan istri yang taat. Pelabelan perempuan semacam ini dilanggengkan secara politik oleh ideologi familialisme yang dianut oleh Indonesia yang menghubungkan negara dan keluarga dengan Soeharto sebagai "Bapak" yang memiliki kewenangan dan melibatkan keluarga (beserta peran gender yang tegas) pada pembangunan nasional. Dalam pandangannya, perempuan memiliki peran utama dan alami untuk melahirkan, membesarkan, dan mendidik anak, serta bertanggung jawab terhadap pekerjaan rumah tangga. Pandangan semacam ini disebut sebagai perpaduan ideologi gender kelompok elit Jawa dan rumah tangga kelompok Borjuis Barat. Sumbangan lain rezim pemerintah dalam

\footnotetext{
${ }^{5}$ Michele Ford and Lyn Parker, 'Introduction', in Women and Work in Indonesia, ed. by Michele Ford and Lyn Parker (Routledge, 2008), p. v.

6 Nicolaas Warouw, 'Industrial Workers in Transition: Women's Experiences of Factory Work in Tangerang', in Women and Work in Indonesia, ed. by Michele Ford and Lyn Parker (Routledge, 2008), pp. 104-5.
} 
pembentukan peran gender adalah digunakannya istilah wanita oleh aparatur negara dalam menyebutkan perempuan ${ }^{7}$.

Kemudian dalam pandangan modern, wanita diartikan sebagai wani nata yang berarti perempuan memiliki potensi dan kekuatan untuk mengatur sehingga perempuan masa kini diidealkan sebagai perempuan yang mampu menjaga kecantikan, anggun, berpikir logis seperti laki-laki dan mampu bekerja keras 8 . Lebih konkrit, perempuan ideal saat ini digambarkan dengan perempuan yang mengikuti jaman dan mampu membahagiakan keluarganya, yaitu perempuan dengan aktivitas ekonomi di luar rumah dan berpenghasilan'.

Isu tentang perempuan sebagai wanita yang wani nata muncul seiring pesatnya industrialisasi di Purbalingga. Sejak beberapa tahun yang lalu, industrialisasi di Purbalingga membuka peluang kerja yang luas bagi perempuan. Hal ini mengakibatkan banyak perempuan melakukan migrasi dari sektor pertanian ke sektor industri denga harapan mendapat upah yang lebih besar dan pasto. Peluang kerja ini tidak ditujukan kepada lakilaki sehingga laki-laki tetap bertahan pada ekonomi pertanian atau pekerjaan lain yang telah ditekuni beserta pendapatannya yang kurang pasti. Kondisi ini memunculkan asumi bahwa perubahan ekonomi perempuan mengakibatkan perubahan pada ketahanan rumah tangga dilihat dari tingginya angka gugatan cerai istri terhadap suami.

Masuknya perempuan pada wilayah industri juga mempengaruhi relasi laki-laki dan perempuan. Perempuan dan laki-laki tidak lagi berrelasi sebagai tenaga kerja di ladang sebagaimana sebelumnya. Perempuan bekerja di pabrik dalam ruang tersendiri dan dengan jam kerja yang telah di atur oleh pihak pabrik. Keterbatasan ruang dan jam kerja yang panjang ini pada akhirnya menuntut perempuan melakukan adaptasi terhadap pembagian kerja di dalam rumah tangga.

\footnotetext{
${ }^{7}$ Keiko Hayami, The Family in Flux in Southeast Asia (Kyoto University Press, 2012).

8 C Kiky, 'Wanita: Dilema Antara "Wani Ditata" Dan "Wani Nata"'”', 2015 <http://www.kompasiana.com/clarasiakikypuspitaanggraeni/wanita-dilemaantara-wani-ditata-dan-wani-nata_5510b012a33311c037ba8a9e>.

9 R Permanadeli, Dadi Wong Wadon; Representasi Sosial Perempuan Jawa Di Era Modern (yogyakarta: Pustaka Ifada, 2015).
} 
Di sisi lain, bekerja di pabrik membuat perempuan memiliki penghasilan berupa uang tunai secara rutin dan memberikan sumbangan yang besar terhadap pemenuhan kebutuhan keluarga. Dengan demikian, jika kebutuhan ekonomi keluarga banyak ditanggung oleh perempuan, apakah perempuan tetap menempati posisi sebagai second class di bawah kekuasaan laki-laki di dalam rumah tangga? Kuasa yang dimaksud dalam penelitian ini merujuk pada power to ${ }^{10}$ di mana kuasa diartikan sebagai kemampuan untuk melakukan sesuatu, bukan power over atau kekuasaan untuk menyuruh atau membuat pihak lain melakukan suatu tindakan. Kekuasaan bersifat abstrak sehingga dalam penelitian ini melihat kuasa melalui pembagian kerja, akses dan kontrol terhadap barang berharga dan kekuatan perempuan dalam pengambilan keputusan di dalam keluarga.

Kajian mengenai kuasa ini akan dilakukan menggunakan analisis gender model Harvard. Kerangka analisis gender model Harvard (Harvard Analitical Framework) merupakan kerangka analisis gender pertama yang dipublikasikan pada tahun 198511. Kerangka analisis gender model Harvard ditujukan untuk penelitian dengan unit analisis yang kecil seperti kelompok dan keluarga atau rumah tangga. Selain itu, identifikasi akses dan kontrol terhadap laki-laki dan perempuan dalam analisis gender Harvard membuat peran dan kerja perempuan lebih terlihat ${ }^{12}$.

Dalam pelaksanaan dan analisisnya, kajian ini menggunakan metode penelitian kualitatif-etnografik. Etnografi memiliki keunggulan mendeskripsikan dan menginterpretasikan budaya dan sistem pada kelompok masyarakat Pasunggingan secara khusus dan "tebal". Pendekatan etnografi yang digunakan dalam penelitian ini bertujuan untuk mendapatkan deskripsi dan analisis yang dalam tentang relasi yang terjadi antara perempuan buruh industri dan laki-laki di dalam keluarga pada masyarakat Desa Pasunggingan Kabupaten Purbalingga berdasarkan sudut pandang masyarakat tersebut (native's point of view). Istilah lain dari the

\footnotetext{
${ }^{10}$ K Dowding, Encyclopedia of Power (Australia: Australia National University, 2011).

${ }^{11}$ Candida March, Inés A Smyth, and Maitrayee Mukhopadhyay, A Guide to GenderAnalysis Frameworks (Oxfam, 1999), p. 32.

12 Prajna Paramita Mishra and M Gopinath Reddy, Gender Mainstreaming in Mining: Experiences Across Countries (Centre for Economic and Social Studies, 2012), p. 7.
} 
native's point of view adalah pandangan emik atau pandangan yang berasal dari subjek penelitian (tineliti), bukan pandangan peneliti terhadap fenomena yang diteliti ${ }^{13}$.

Kajian ini berlokasi di Desa Pasunggingan, Kecamatan Pengadegan, Kabupaten Purbalingga. Dibandingkan dengan desa lain yang memiliki jumlah penduduk lebih tinggi, yaitu Desa Pengadegan dengan jumlah penduduk 9270 jiwa dengan jumlah buruh industri sekitar 12\%, Desa Pasunggingan memiliki jumlah buruh industri lebih tinggi yaitu 1081 atau hampir $20 \%$ dari $5.432^{14}$. Selain itu, Pasunggingan memiliki prosentase perceraian yang cukup tinggi yaitu sekitar 1:315. Tingginya jumlah buruh dan angka perceraian ini memunculkan asumsi masyarakat bahwa penghasilan perempuan dari bekerja sebagai buruh telah menempatkan kekuasaan perempuan pada posisi yang lebih tinggi dari laki-laki khususnya dalam mengatur kehidupan rumah tangga.

Munculnya asumsi-asumsi tersebut mendorong peneliti melakukan kajian ini untuk memberikan pemahaman analitis etnografis tentang pengaruh industrialisasi terhadap kekuasaan perempuan di wilayah domestik di lihat dari aktivitas, akses, dan kontrol perempuan buruh terhadap barang mewah dan pengambilan keputusan. selain itu, penelitian ini juga dilakukan untuk melihat dinamika sosial ekonomi yang muncul pada masyarakat di Desa Pasunggingan, khususnya yang dialami oleh perempuan buruh.

\section{HASIL DAN PEMBAHASAN}

\section{Pabrik Bulu Mata Palsu dan Ekonomi Desa Pasunggingan}

Berdasarkan beberapa sumber tulisan ${ }^{16}$, industri bulu mata palsu di Purbalingga pertama muncul pada tahun 1967 saat Hyung Sang Lee

\footnotetext{
${ }^{13}$ James P Spradley, Participant Observation (Waveland Press, 2016).

14 Data pada tahun 2016 yang diambil dari data milik Badan Perencanaan dan Pembangunan Daerah.

15 Berdasarkan perhitungan Peneliti dari catatan Desa tentang pernikahan dan cerai/talaq tahun 2016

16 G.M Rejeki, S. dan Finesso, 'Bulu Mata Purbalingga Menyihir Dunia', 2014 $<$ http://bisniskeuangan.kompas.com/read/2014/06/02/1518008/Bulu.Mata.Purbaling ga.Menyihir.Dunia>. A. Andrianto, 'Ada Keringat Buruh Purbalingga Di Bulu Mata
} 
memindahkan pabriknya yang bernama Royal Kenny dari Korea Selatan ke Purbalingga. Kemunculan pabrik ini diikuti oleh pabrik-pabrik lain yang memproduksi rambut palsu dan bulu mata palsu pada tahun 2000an, baik pabrik milik lokal maupun milik asing. Pabrik bulu mata palsu Purbalingga menjadi pabrik bulu mata terbesar nomor dua setelah Ghuangzhou, Cina dan menjadi satu-satunya produsen bulu mata palsu dengan bahan baku rambut asli manusia.

Pabrik bulu mata palsu membuka banyak peluag kerja dan mampu menyerap lebih dari 50.000 tenaga kerja lokal yang sebagian besar adalah perempuan. Angka ini tidak termasuk perempuan-perempuan yang bekerja di luar pabrik pusat seperti pada pabrik cabang dan bekerja di rumah dengan sistem putting out. Pabrik cabang industri bulu mata palsu telah tersebar di berbagai Desa di Kabupaten Purbalingga, salah satunya Desa Pasunggingan Kecamatan Purbalingga.

Desa Pasunggingan berada di Kecamatan Pengadegan, Kabupaten Purbalingga, sekitar lebih dari $30 \mathrm{~km}$ dari pusat Kabupaten dengan waktu tempuh sekitar 20 menit menggunakan kendaraan pribadi karena wilayah desa tidak di akses oleh kendaraan umum.

Desa Pasunggingan adalah wilayah desa dengan 81\% luas wilayah Desa berupa perkebunan atau tegalan17 sehingga pertanian adalah sumber ekonomi andalan masyakarat. Bidang pertanian ini tidak hanya dikerjakan oleh laki-laki namun juga perempuan. Penghasilan yang diperoleh dari panen pertanian memiliki nominal yang cukup besar namun menjadi sumber pemasukan utama untuk beberapa bulan berikutnya sampai panen

Katy Perry', Liputan 6, 18 October 2016. G Chamberlain, 'Sore Eyes, Bad Back, Low Pay: The Cost of False Eyelash Glamour', 2013 $<$ https://www.theguardian.com/world/2013/dec/28/false-eyelash-industryindonesia-low-pay>. Pikiran Rakyat, 'Rambut Dan Bulu Mata Palsu Sumbang Pendapatan Tertinggi', $2011 \quad<$ http://www.pikiranrakyat.com/ekonomi/2011/01/27/133503/rambut-dan-bulu-mata-palsu-sumbangpendapatan-tertinggi>.

17 Pemerintah Desa Pasunggingan, Peraturan Desa Pasunggingan Nomor 01 Tahun 2014 Tentang Rencana Pembangunan Jangka Menengah Desa (RPJM-Desa) Tahun 20142019 (Pemerintah Desa Pasunggingan, 2014). 
selanjutnya. Penghasilan panen dialokasikan untuk kebutuhan rumah tangga, pendidikan anak, dana sosial, dan biaya pengelolaan lahan seperti membeli bibit baru, pupuk, membayar buruh yang mencangkul (macul) dan membersihkan rumput liar (bedhog). Kebutuhan rumah tangga seperti makan, pemeliharaan rumah, pemeliharaan kendaraan dan cicilan kreditbagi yang memiliki, dan biaya pendidikan anak merupakan kebutuhan rutin yang bersifat jangka pendek. Kebutuhan-kebutuhan tersebut menjadi kebutuhan yang tidak dapat tertunda jika uang hasil panen mulai menipis. Untuk memenuhi kebutuhan tersebut, petani menanam tanaman tambahan yang dapat dijual sewaktu-waktu seperti kelapa dan pisang, juga mencari penghasilan lain sebagai buruh tani sambil menunggu panen milik sendiri.

Bekerja sebagai buruh tani memberikan penghasilan yang tidak cukup banyak. Dalam sekali bekerja, buruh mendapatkan upah sekitar Rp 25.000 dengan besarnya tenaga fisik dan panjangnya jam kerja. Kebutuhankebutuhan tersebut tidak semerta-merta menjadi tanggungan laki-laki. Banyak perempuan turut serta menjadi buruh untuk memenuhi kebutuhan keluarga karena permasalahan keuangan dalam keluarga menjadi beban perempuan sebagai pengatur wilayah domestik seperti penyedia makanan dan tempat anak meminta uang.

Dalam kondisi demikian, pabrik hadir menawarkan pekerjaan berupah rutin yang dapat diperoleh dalam waktu singkat dan dengan sistem kerja yang dinilai lebih ringan daripada bekerja di kebon. Sebagaimana diungkapkan oleh $\mathrm{S}$, seorang buruh pabrik yang sebelumnya bekerja sebagai buruh tani bahwa"Ya mending-mendinga ngidep. Genah. Panas ora kepanasen. Udan ora kudanen. Tiba ngathang-ngathang juga tau gara-gara kepleset nggendong budin udan-udan" ( lebih baik ngidep. Jelas. Kalau cuaca panas, tidak kepanasan. Kalau hujan, tidak kehujanan. Jatuh terlentang juga pernah karena terpeleset mengangkut singkong saat hujan).

Pabrik menawarkan pekerjaan dengan akses administrasi dan geografis yang mudah dijangkau sehingga banyak perempuan kemudian beralih ke dalam pekerjaan sebagai buruh pabrik. Saat ini, bekerja sebagai buruh pabrik menjadi pekerjaan yang diminati banyak perempuan dari semua kalangan. 
Bekerja di parik bulu mata palsu disebut dengan ngidep. Sedangkan perempuan yang ngidep mendapat sebutan sebagai tukang ngidep. Ngidep berasal dari kata idep yang berarti bulu mata. Idep kemudian mendapat imbuhan nge- yang menerangkan kata kerja. Ngidep dikerjakan di dalam rumah maupun di cabang pabrik bulu mata palsu yang disebut idepan.

Perempuan yang beralih pekerjaan menjadi tukang ngidep bukan hanya perempuan dari buruh tani namun juga buruh-buruh di sektor informal yang bekerja di perantauan. Ngidep di Desa menawarkan pekerjaan tanpa meninggalkan keluarga karena lokasinya yang dekat dengan rumah . Selain itu, ngidep di dekat rumah menurangi biaya ekonomi untuk membayar tempat tinggal dan makan sebagaimana jika bekerja di perantauan.

\section{Migrasi Perempuan ke dalam Pabrik}

Terdapat beberapa alasan perempuan melakukan migrasi menjadi tukang ngidep. Pertama, alasan ekonomi. Sebagian besar suami perempuan buruh industri adalah petani dengan penghasilan yang tidak pasti dan rutin, seperti buruh bangunan, buruh dagang, dan buruh serabutan. Saat kebutuhan keluarga meningkat sedangkan penghasilan suami tidak menentu, perempuan sebagai pedaringan keluarga dituntut mencari jalan keluar dan memikirkan penyelesaian. Pedaringan merupakan tempat penyimpanan beras atau padi. Filosofi pedaringan menggambarkan bahwa perempuan memiliki tanggung jawab dalam menyediakan makanan bagi keluarga. Perempuan harus mampu mengatur pemasukan dan pengeluaran keluarga agar kebutuhan makan keluarga sebagai kebutuhan pokok dapat terpenuhi. Dalam kondisi ini, ngidep menjadi alternatif utama bagai perempuan untuk memperoleh penghasilan. Alasan ini banyak diungkapkan oleh buruh yang sudah berumah tangga seperti T bahwa "Ora isin-isin Mbak, wong jenenge butuh. Nek isin ya ora ngidep, ora ngidep ya ora olih duit" (Tidak malu Mbak, demi kebutuhan. Kalau malu berarti tidak ngidep. Kalau tidak ngidep berarti tidak punya uang).

Selain alasan ekonomi, alasan kedua yang mendorong perempuan bekerja di pabrik bulu mata palsu adalah adanya kebutuhan psikologis dan sosial. Sebagaimana di Desa Pasunggingan, beberapa buruh berasal dari 
keluarga dengan ekonomi yang cukup mapan. Namun, status ibu rumah tangga yang dianggap monoton dan membosankan mendorong perempuan untuk berkumpul dengan sesamanya di dalam pabrik. Salah satu buruh menyebutkan bahwa "Daripada neng umah bae ya bosen mung kaya kae tok gaweane, ya mending ngidep ketemu batir kena nggo lumanyanan"(Dari pada di rumah saja membosankan, pekerjaannya itu-itu saja, lebih baik bekerja ke pabrik bertemu teman).

Adanya kebutuhan perempuan terhadap ekonomi maupun psikososial tersebut disambut oleh mudahnya sistem seleksi yang ditawarkan oleh pihak pabrik. Idepan membuka kesempatan kerja seluasluasnya bagi perempuan dari semua latar belakang pendidikan, umur, keahlian, ketrampilan, pengalaman kerja, kepribadian dan kesehatan. Pabrik memiliki persyaratan pendaftaran yang ringan dan proses seleksi tanpa tes. Bekerja di pabrik hanya membutuhkan kemauan untuk bekerja.

Secara administratif, pabrik membuka lowongan tanpa meminta syarat selain fotocopy KTP dan tanpa memberikan tes seleksi. Penawaran semacam ini menjadi keuntungan perempuan desa dari semua kalangan yang sebagian besar berpendidikan setingkat SD dan SMP bahkan tidak memiliki ijazah sekolah.

Secara geografis, lokasi pabrik berada di dalam desa yang mudah dijangkau dengan waktu yang singkat. Kemudahan akses geografis membuat perempuan dapat meluangkan waktu lebih banyak untuk mengurus anak dan pekerjaan rumah tangga lainnya. Perempuan buruh dapat berangkat beberapa menit sebelum jam masuk kerja bersamaan dengan mengantar anak ke sekolah. Perempuan tidak perlu khawatir dengan terbatasnya transportasi umum yang tidak dimiliki desa. Buruh yang tidak memiliki kendaraan dapat bekerja dengan berjalan kaki atau pergi bersama teman buruh yang tinggal berdekatan.

\section{Perempuan dalam Pembagian Kerja}

Bekerja di luar rumah meruakan aktivitas yang tidak lagi baru bagi perempuan di Desa Pasunggingan. Namun, bekerja sebagai buruh industri menjadi hal yang cukup baru karena sistem kerja lebih terstruktur sepert jam kerja yang cukup panjang sejak pagi sampai sore. Hal ini membuat 
perempuan buruh khususnya yang berstatus menikah harus beradaptasi sehingga pekerjaan domestik dan pabrik sama-sama dapat terselesaikan.

Terdapat beberapa cara perempuan menyesuaikan diri dengan pekerjaan pabrik dan domestik, yaitu menyelesaikan pekerjaan rumah tangga secara lebih cepat sebelum bekerja di pabrik, menunda pekerjaan rumah tangga sampai jam kerja pabrik selesai, dan membuka rumah tangga dengan cara membawa pekerjaan rumah tangga ke dalam pabrik atau melibatkan pihak lain untuk menyelesaikan pekerjaan di dalam rumah tangga.

Cara-cara adaptasi buruh dalam mengambil langkah penyesuaian pekerjaan rumah tangga dan pabrik banyak mendapat pengaruh dari bentuk keluarga yang dimiliki. Buruh yang tinggal membentuk rumah tangga bersama keluarga orang tua memiliki lebih banyak kemudahan karena dapat membagi pekerjaan dengan orang tua khususnya Ibu. Beberapa pekerjaan yang perempuan kerjakan bersama orang tua adalah menyediakan makanan, perlindungan kesehatan, pemeliharaan rumah, pengasuhan anak, dan pekerjaan lain selain mencuci pakaian. Diantara pekerjaan-pekerjaan tersebut, pengasuhan anak menjadi pekerjaan yang paling kaku karena harus dilakukan sepanjang waktu dan tidak dapat ditunda. Pengasuhan anak juga menjadi pekerjaan yang tidak mungkin dilimpahkan kepada orang lain selain orang tua atau kerabat karena melibatkan pengasuh dari luar keluarga membutuhkan biaya besar sedangkan upah buruh tidak mencukupi. Strategi semacam ini dilakukan salah satunya oleh I yang memiliki anak berusia 3 tahun. Setiap hari, I harus berangkat ke pabrik secara sembunyi-sembunyi agar anaknya yang berusia 3 tahun tidak ikut ke pabrik. Jika anaknya tidak mau ditinggal di rumah, maka I akan membawa anaknya ke pabrik. Namun jika anaknya berhasil ditinggal, maka anak I anak diasuh oleh neneknya dan kadang ikut sepupunya bermain ke sekolah PAUD.

Cara lain yang buruh lakukan agar pekerjaan domestik dan pabrik dapat berjalan beriringan adalah membawa pekerjaan domestik ke dalam pabrik. Pekerjaan domestik yang dapat dibawa ke dalam pabrik adalah menyediakan makanan. Setiap pagi dan siang, terdapat penjual makanan yang datang berkeliling ke dalam pabrik. Penjual menjual berbagai macam 
makanan berupa nasi jagung, lauk pauk dan sayur yang telah matang, serta kue tradisional. Setelah membeli makanan, buruh akan mengantarnya ke rumah di sela-sela jam kerja atau membawanya pulang saat jam kerja selesai.

Uraian mengenai aktivitas buruh di atas memperlihatkan bahwa pekerjaan rumah tangga tetep melekat pada perempuan sekalipun perempuan memiliki pekerjaan di luar rumah dan untuk menyelesaikan kedua jenis pekerjaan tersebut perempuan membangun jaringan-jaringan sosial ekonomi. Perampuan melibatkan orang lain baik dari dalam keluarga inti, keluarga besar bersama orang tua, dan pihak lain di luar keluarga untuk menyelesaikan pekerjaan domestik. Hal ini menandakan bahwa cakupan rumah tangga tidak terbatas dalam satu wilayah rumah atau antar rumah (somah), namun rumah tangga adalah ruang terbuka di mana perempuan bisa menghadirkan pihak lain di luar penghuni rumah untuk menjaga keseimbangan ekonomi. Selain itu, rumah tangga bukanlah benda yang statis namun sebuah ruang dinamis yang dapat dibawa ke manamana seperti ke dalam pabrik.

\section{Akses dan Kontrol Perempuan terhadap Sumber Daya dan Keputusan}

Sumber daya yang dimaksud dalam hal ini adalah barang berharga dengan nilai ekonomis tinggi untuk keberlangsungan hidup diri dan keluarga. Barang berharga yang paling mencolok dalam kehidupan masyarakat Pasunggingan adalah tanah, hewan ternak, perhiasan, kendaraan, dan uang. Barang berharga dalam keluarga masyarakat ini biasanya dapat diakses oleh laki-laki dan perempuan namun tidak semua barang tersebut dikontrol oleh laki-laki dan perempuan. Diantara beberapa barang berharga di atas, pendapatan dari ngidep menjadi barang berharga utama milik perempuan yang dapat diputar menjadi barang berharga lain seperti perhiasan dan kendaraan. Namun, kenyataannya perempuan tidak sepenuhnya merdeka dalam menggunakan pendapatan yang dimilikinya. Sebagian perempuan harus merelakan pendapatnnya untuk memenuhi kebutuhan keluarga dan mengesampingkan kebutuhan dan keinginan pribadi. 
Barang berharga lain yang menjadi fokus dalam penelitian ini adalah barang-barang bernilai ekonomis tinggi yang biasanya disahkan dengan surat atau sertifikat seperti kendaraan, perhiasan, dan tanah. Dalam hal ini, terjadi pemisahan kepemilikan yang sangat jelas yang cenderung mengarah pada kontrol laki-laki dan perempuan. Pemilik yang sah secara sertifikat menjadi pemegang kendali atau kontrol atas barang tersebut. Penegasan pemisahan kepemilikan barang juga biasanya ditandai dengan penyebutan kata ganti kepemilikan dalam menyebutkan barang, misalnya "motore bapane, motore nyong, motore rika" (Motor milik Bapak, motor saya, motor anda). Penyebutan kepemilikan menjadi penguat pemisahan barang berharga karena secara administrasi kepemilikan dapat terulis atas nama laki-laki sebagai pihak yang mengurus pembelian dan administrasi namun hak guna berada pada kedua pihak. Kepemilikan perempuan secara penuh secara administrasi dan hak guna terjadi pada kepemilikan perhiasan yang perempuan beli secara langsung baik dengan uang sendiri maupun uang sisa pemberian suami. Perempuan menyimpan dan menyisihkan pendapatannya atau uang milik suami saat surplus untuk perhiasan. Perhiasan memiliki nilai estetika dan ekonomis bagi perempuan buruh karena menjadi barang investasi yang akan dijual saat keluarga membutuhkan uang.

Posisi buruh dalam akses dan kontrol terhadap barang berharga di dalam keluarga tidak dapat dilihat dalam bingkai yang seragam. Akses dan kontrol buruh terkait dengan nilai tawar di dalam rumah tangga, sedangkan nilai tawar dapat berubah sesuai dengan posisi dan status buruh di dalam keluarga dan rumah tangga. Misalnya, perempuan yang tinggal membentuk rumah tangga bersama keluarga orang tua dapat memiliki nilai tawar yang rendah saat berada pada struktur rumah tangga karena berposisi sebagai anak, namun dapat memiliki nilai tawar yang kuat saat berada pada keluarga ini karena perempuan berposisi sebagai ahli waris kekayaan orang tua. Kompleksitas semacam ini tidak berlaku pada perempuan yang hanya tinggal bersama keluarga inti. Perempuan yang tinggal serumah hanya dengan suami dan anak menghadapi struktur keluarga inti di mana perempuan berposisi sebagai istri dan ibu. Dalam hal ini pengelolaan aset dan pengambilan keputusan cenderung dilakukan 
bersama namun kontrol tetap berada di tangan laki-laki suami, seperti saat menentukan harga panen yang disepakati bersama juragan dan melakukan transaksi jual beli ternak. kasus-kasus seperti demikian menegaskan bahwa pendapatan menjadi salah satu sumber daya namun bukan satu-satunya sumber daya yang menentukan posisi tawar perempuan. Terdapat faktor lain di luar pendapatan yang mempengaruhi posisi perempuan di dalam struktur, seperti faktor budaya, sosial dan agama yang dianut masyarakat.

Dalam kasus lain di keluarga perempuan buruh, memiliki suami sebagai kapala keluarga yang sah secara administrasi tidak selalu menjamin suami sebagai pihak yang dijadikan rujukan dalam pengambilan keputusan. Hal ini berlaku bagi buruh yang tinggal dalam rumah milik orang tua dan sebagian besar biaya hidup dari hasil ngidep, perempuan banyak menggunakan merujuk orang tua untuk mengambil keputusan. Orang tua adalah pihak pertama dan pemilik suara terkuat di dalam keluarga inti perempuan maupun keluarga besar orang tua. Keputusan keluarga berada pada persetujuan maupun ketidaksetujuan orang tua khususnya Bapak. Pentingnya orang tua bagi keluarga perempuan buruh yang tinggal membentuk rumah tangga bersama keluarga orang tua tidak hanya orang tua sebagai penentu keputusan keluarga, namun juga orang tua sebagai imam.

Pada akhirnya, perempuan sama halnya dengan laki-laki. Perempuan bekerja dan menggunakan hasil kerjanya untuk kebutuhan keluarga. Sumbangan perempuan dalam pemenuhan keluarga memposisikan perempuan pada tempat yang penting dalam struktur ekonomi keluarga. Perempuan memberikan pemasukan rutin bagi keluarga berarti perempuan memberikan modal dalam kelangsungan hidup keluarga. Pada beberapa keluarga, upah ngidep menjadi modal terbesar berlangsungnya sistem ekonomi keluarga. Masuknya perempuan sebagai penyedia modal ekonomi keluarga menempatkan perempuan pada nilai tawar yang lebih tinggi. Laki-laki melibatkan perempuan dalam pengambilan keputusan yang berhubungan dengan perubahan modal ekonomi di dalam keluarga karena modal yang akan berubah tidak hanya modal milik suami, namun juga modal ekonomi dari hasil kerja perempuan. 


\section{Perempuan dalam Kegiatan Sosial}

Dalam istilah masyarakat, kegiatan sosial disebut juga dengan srawung. Beberapa jenis srawung yang umum dilakukan oleh perempuan dan laki-laki di Desa Pasunggingan, yaitu srawung dalam kegiatan keagamaan dan kegiatan sosial. Kegiatan keagamaan pada masyarakat Pasunggingan biasanya berlangsung dalam kelompok-kelompok kecil yang tersebar dalam masing-masing RT, RW dan dusun seperti kelompok yasinan, kelompok tariqah, dan kelompok majelis ta'lim. Kelompokkelompok ini kemudian terbagi lagi menjadi kelompok berdasarkan jenis kelamin atau kelompok laki-laki dan perempuan berlangsung secara terpisah. Bergabungnya buruh dalam kelompok sosial keagamaan ini merupakan bentuk penyeimbangan antara kebutuhan dunia dan akhirat, sebagaimana diungkapkan oleh buruh T "Kerja terus juga mboten sae Mbak, kudu eling gusti Allah. Isin mba nek mboten pangkat karena ngidep" (Kerja terus juga tidak bagus Mba, harus ingat dengan Allah. Malu juga Mba kalau tidak berangkat hanya karena ngidep)".

Kelompok yasinan laki-laki memiliki agenda yang lebih padat dibandingkan kelompok perempuan. Hal ini dikarenakan kelompok lakilaki banyak menerima undangan untuk menghadiri slametan masyarakat di luar agenda rutin. Berbeda dengan laki-laki, yasinan perempuan hanya berlangsung dalam acara rutin karena perempuan dalam acara slametan berada di wilayah belakang untuk menyiapkan makanan. Slametan identik dengan dua hal yaitu makan dan doa bersama. Proses penyiapan makanan berada pada ruang belakang rumah yang menjadi tugas perempuan, sedangkan doa berlangsung pada ruang depan yang dilakukan oleh kelompok laki-laki. Rantai kerja laki-laki dan perempuan juga muncul dalam kegiatan sosial lain seperti gotong royong perbaikan jalan dan fasilitas umum di mana laki-laki tampil sebagai pelaku di ruang depan yang menyentuh pekerjaan secara langsung sedangkan perempuan terlibat di belakang sebagai penyedia makanan.

Bentuk lain srawung yang umum terdapat pada masyarakat Pasunggingan adalah nyumbang. Nyumbang adalah kegiatan memberikan sumbangan kepada tetangga atau kerabat yang memiliki hajatan 
menikahkan anak dan atau mengkhitankan anak, biasanya dalam bentuk bahan makanan. Nyumbang juga berlaku jika kerabat mengadakan renovasi rumah sebagai bentuk bantuan terhadap sesama. Dari nyumbang, perempuan akan pulang dengan berkat atau makanan matang sebagai bentuk ucapan terima kasih atas sumbangan yang telah diberikan. Istilah nyumbang hanya berlaku pada kelompok perempuan. Nyumbang dalam kelompok laki-laki disebut sebagai kondangan dengan barang yang diberikan berupa uang dan tidak mendapat tanda terima kasih sebagaimana perempuan.

Nyumbang dan kondangan memerlukan biaya yang tidak kecil. Dalam sekali memberikan sumbangan, perempuan dapat menghabiskan uang kurang lebih 50.000 sampai ratusan ribu sesuai hubungan kekerabatan perempuan dengan si pemilik hajat. Dana srawung pada jenis ini menjadi beban ekonomi perempuan karena di satu pihak perempuan harus pandai mengatur uang pemberian suami untuk kebutuhan rumah tangga namun di pihak lain perempuan dituntut untuk melaksanakan swarung kepada kerabat dan tetangga. Oleh karena itu, penghasilan yang perempuan peroleh dari bekerja di pabrik memungkinkan perempuan memiliki ruang sosial yang lebih luas karena mampu memenuhi kebutuhan sosial dan mampu membuka diri pada lingkungan sosial yang lebih terbuka melalui pembiayaan srawung.

\section{SIMPULAN}

Pabrik bulu mata palsu hadir sebagai struktur yang baru di dalam kehidupan perempuan Desa Pasunggingan. Pabrik menjadi tempat perempuan memperoleh pendapatan secara rutin sekaligus menjadi tempat perempuan mengumpulkan sumber daya ekonomi yang menjadi sumber kontestasi nilai tawar perempuan di dalam keluarga dan rumah tangga. Alih-alih konstruksi budaya menempatkan perempuan sebagai penanggung jawab pekerjaan domestik, perempuan menjadikan tanggung jawab domestik tersebut sebagai kewenangan untuk membuka rumah tangga menjadi wilayah yang lebih luas. Perempuan tidak dapat menarik laki-laki ke dalam pekerjaan domestik, namun perempuan mampu menarik 
pihak lain ke dalam wilayah domestik dan atau membawa pekerjaan rumah tangga keluar pada wilayah yang lebih luas seperti pabrik.

Lebih dari membuka rumah tangga, penghasilan perempuan dari bekerja di pabrik mengantarkan perempuan sebagai penyangga keberlangsungan keluarga baik secara ekonomi maupun sosial. Secara sosial, penghasilan perempuan dari bekerja sebagai buruh bulu mata palsu mampu membiayai kebutuhan perempuan dan keluarga terhadap kegiatan sosial sehingga eksistensi perempuan dan keluarga di dalam struktur masyarakat yang lebih luas dapat terjaga. 


\section{DAFTAR PUSTAKA}

Andrianto, A., 'Ada Keringat Buruh Purbalingga Di Bulu Mata Katy Perry', Liputan 6, 18 October 2016

Benjamin, D, 'Women and the Labour Market in Indonesia during the 1980s', in Women and Industrialization in Asia, ed. by Susan Horton (New york: Routledge, 2003)

Chamberlain, G, 'Sore Eyes, Bad Back, Low Pay: The Cost of False Eyelash Glamour', 2013

<https://www.theguardian.com/world/2013/dec/28/false-eyelashindustry-indonesia-low-pay>

Dowding, K, Encyclopedia of Power (Australia: Australia National University, 2011)

Ford, Michele, and Lyn Parker, 'Introduction', in Women and Work in Indonesia, ed. by Michele Ford and Lyn Parker (Routledge, 2008)

Hayami, Keiko, The Family in Flux in Southeast Asia (Kyoto University Press, 2012)

Kiky, C, 'Wanita: Dilema Antara “Wani Ditata” Dan “Wani Nata"'”, 2015 <http://www.kompasiana.com/clarasiakikypuspitaanggraeni/wanitadilema-antara-wani-ditata-dan-wani-nata_5510b012a33311c037ba8a9e>

March, Candida, Inés A Smyth, and Maitrayee Mukhopadhyay, A Guide to Gender-Analysis Frameworks (Oxfam, 1999)

Mishra, Prajna Paramita, and M Gopinath Reddy, Gender Mainstreaming in Mining: Experiences Across Countries (Centre for Economic and Social Studies, 2012)

Pasunggingan, Pemerintah Desa, Peraturan Desa Pasunggingan Nomor 01 Tahun 2014 Tentang Rencana Pembangunan Jangka Menengah Desa (RPJM-Desa) Tahun 2014-2019 (Pemerintah Desa Pasunggingan, 2014)

Permanadeli, R, Dadi Wong Wadon; Representasi Sosial Perempuan Jawa Di Era Modern (yogyakarta: Pustaka Ifada, 2015) 
Purwanto, Erwan Agus, and Budhy K Zaman, Ups and Downs in Rural Javanese Industry: The Dynamics of Work and Life of Small-Scale Garment Manufacturers and Their Families (Grha Guru, 2005)

Rakyat, Pikiran, 'Rambut Dan Bulu Mata Palsu Sumbang Pendapatan Tertinggi', 2011 $<$ http://www.pikiranrakyat.com/ekonomi/2011/01/27/133503/rambut-dan-bulu-mata-palsusumbang-pendapatan-tertinggi $>$

Rejeki, S. dan Finesso, G.M, 'Bulu Mata Purbalingga Menyihir Dunia', 2014 $<$ http://bisniskeuangan.kompas.com/read/2014/06/02/1518008/Bulu.Ma ta.Purbalingga.Menyihir.Dunia>

Sapari, Ratna, and Briggitte Holzner, Perempuan Kerja Dan Perubahan Sosial (Jakarta: P.T Pustaka Utama Grafiti, 1997)

Setia, Resmi, 'Perjalanan Hidup Seorang Buruh Perempuan (Antara Rumah Tangga, Tempat Kerja Dan Komunitas)', Jurnal Analisis Sosial, 8 (2003), $51-63$

Spradley, James P, Participant Observation (Waveland Press, 2016)

Warouw, Nicolaas, 'Industrial Workers in Transition: Women's Experiences of Factory Work in Tangerang', in Women and Work in Indonesia, ed. by Michele Ford and Lyn Parker (Routledge, 2008)

Warto, 'Wanita Pabrikan: Simbol Pergeseran Status Wanita Desa', in Sangkan Paran Gender (Yogyakarta: Pustaka Pelajar, 2006)

Andrianto, A., 'Ada Keringat Buruh Purbalingga Di Bulu Mata Katy Perry', Liputan 6, 18 October 2016

Benjamin, D, 'Women and the Labour Market in Indonesia during the 1980s', in Women and Industrialization in Asia, ed. by Susan Horton (New york: Routledge, 2003)

Chamberlain, G, 'Sore Eyes, Bad Back, Low Pay: The Cost of False Eyelash Glamour', 2013

$<$ https://www.theguardian.com/world/2013/dec/28/false-eyelash- 
industry-indonesia-low-pay>

Dowding, K, Encyclopedia of Power (Australia: Australia National University, 2011)

Ford, Michele, and Lyn Parker, 'Introduction', in Women and Work in Indonesia, ed. by Michele Ford and Lyn Parker (Routledge, 2008)

Hayami, Keiko, The Family in Flux in Southeast Asia (Kyoto University Press, 2012)

Kiky, C, 'Wanita: Dilema Antara “Wani Ditata” Dan “Wani Nata'”"', 2015 $<$ http://www.kompasiana.com/clarasiakikypuspitaanggraeni/wanitadilema-antara-wani-ditata-dan-wani-nata_5510b012a33311c037ba8a9e>

March, Candida, Inés A Smyth, and Maitrayee Mukhopadhyay, A Guide to Gender-Analysis Frameworks (Oxfam, 1999)

Mishra, Prajna Paramita, and M Gopinath Reddy, Gender Mainstreaming in Mining: Experiences Across Countries (Centre for Economic and Social Studies, 2012)

Pasunggingan, Pemerintah Desa, Peraturan Desa Pasunggingan Nomor 01 Tahun 2014 Tentang Rencana Pembangunan Jangka Menengah Desa (RPJM-Desa) Tahun 2014-2019 (Pemerintah Desa Pasunggingan, 2014)

Permanadeli, R, Dadi Wong Wadon; Representasi Sosial Perempuan Jawa Di Era Modern (yogyakarta: Pustaka Ifada, 2015)

Purwanto, Erwan Agus, and Budhy K Zaman, Ups and Downs in Rural Javanese Industry: The Dynamics of Work and Life of Small-Scale Garment Manufacturers and Their Families (Grha Guru, 2005)

Rakyat, Pikiran, 'Rambut Dan Bulu Mata Palsu Sumbang Pendapatan Tertinggi', $\quad 2011 \quad<$ http://www.pikiranrakyat.com/ekonomi/2011/01/27/133503/rambut-dan-bulu-mata-palsusumbang-pendapatan-tertinggi>

Rejeki, S. dan Finesso, G.M, 'Bulu Mata Purbalingga Menyihir Dunia', 2014 <http://bisniskeuangan.kompas.com/read/2014/06/02/1518008/Bulu.Ma 
ta.Purbalingga.Menyihir.Dunia>

Sapari, Ratna, and Briggitte Holzner, Perempuan Kerja Dan Perubahan Sosial (Jakarta: P.T Pustaka Utama Grafiti, 1997)

Setia, Resmi, 'Perjalanan Hidup Seorang Buruh Perempuan (Antara Rumah Tangga, Tempat Kerja Dan Komunitas)', Jurnal Analisis Sosial, 8 (2003), $51-63$

Spradley, James P, Participant Observation (Waveland Press, 2016)

Warouw, Nicolaas, 'Industrial Workers in Transition: Women's Experiences of Factory Work in Tangerang', in Women and Work in Indonesia, ed. by Michele Ford and Lyn Parker (Routledge, 2008)

Warto, 'Wanita Pabrikan: Simbol Pergeseran Status Wanita Desa', in Sangkan Paran Gender (Yogyakarta: Pustaka Pelajar, 2006)

Data Badan Perencanaan dan Pembangunan Daerah pada tahun 2016 